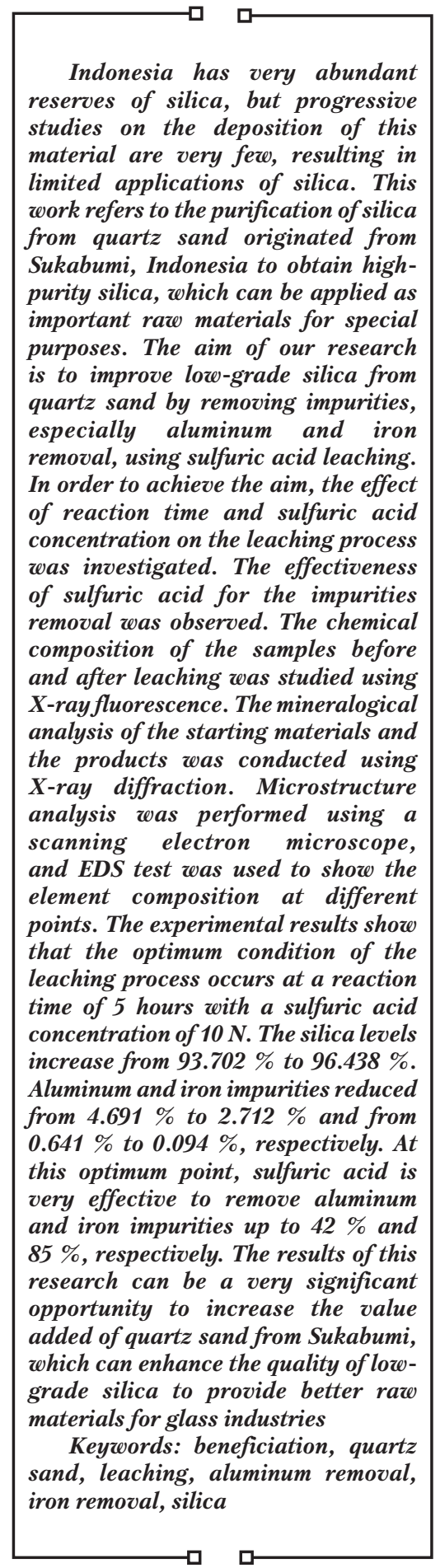

\title{
IMPLEMENTATION OF SULFURIC ACID LEACHING FOR ALUMINUM AND IRON REMOVAL FOR IMPROVEMENT OF LOW-GRADE SILICA FROM QUARTZ SAND OF SUKABUMI, INDONESIA
} of reaction time and sulfuric acid composition of the samples before and after leaching was studied using $X$-ray fluorescence. The mineralogical element composition at different points. The experimental results show that the optimum condition of the Aluminum and iron impurities reduced from $4.691 \%$ to $2.712 \%$ and from $0.641 \%$ to $0.094 \%$, respectively. At this optimum point, sulfuric acid is very effective to remove aluminum $85 \%$, respectively. The results of this added of quartz sand from Sukabumi, which can enhance the quality of lowgrade silica to provide better raze

and, leaching, aluminum removal, iron removal, silica

\author{
Eko Sulistiyono \\ Master of Science* \\ Murni Handayani \\ Corresponding author \\ Doctor of Philosophy * \\ E-mail: murn001@lipi.go.id \\ Agus Budi Prasetyo \\ Doctor of Engineering* \\ Januar Irawan \\ Bachelor of Engineering* \\ Eni Febriana \\ Master of Science* \\ Florentinus Firdiyono \\ Doctor of Engineering, Professor* \\ Erlina Yustanti \\ Doctor of Material Science** \\ Safetyana Nazaretha Sembiring \\ Bachelor of Engineering** \\ Firdaus Nugroho \\ PT Powertech Nano Industri \\ Gedung TBIC Puspiptek, Zona Bisnis Teknologi Kawasan Puspiptek, \\ Jl. Raya Puspiptek, Gunung Sindur, Bogor, Indonesia \\ Ersan Yudhapratama Muslih \\ Master of Science and Engineering \\ Department of Mechanical Engineering \\ Trisakti University \\ Jalan Kyai Tapa, 1, Grogol Petamburan, Jakarta, Indonesia, 11440 \\ *Research Centre for Metallurgy and Material \\ Indonesian Institute of Sciences \\ **Department of Metallurgical Engineering \\ Sultan Ageng Tirtayasa University \\ Cilegon Banten, Indonesia 42435
} Building 470, Kawasan Puspiptek Serpong, Tangerang Selatan, Indonesia, 15314

\section{Introduction}

Silica $\left(\mathrm{SiO}_{2}\right)$ is one of the most abundant materials and is used in very broad applications in ceramic, glass, refractory, paper, rubber and other industries. Nevertheless, few deposits match in quality and reliability to suit the purification method for specific applications [1]. High-purity silica both in the form of quartz sand and precipitated silica has a very high selling value. Silica with a high level of purity is applied as important raw materials for special purposes, which have very strict requirements for quality [2,3]. High-purity silica is widely used in the glass industry $[1,4-6]$ and semiconductor industry for electronic components, optical fiber for communication and internet networks, solar panels [7-12], as well as in the catalytic chemistry industry for the synthesis of catalysts and adsorbent materials $[3,4,13]$. The $\mathrm{SiO}_{2}$ con- 
tent ranges from $94.5 \%$ for low-quality silica such as glass for insulating fibers to $99.7 \%$ for optical and ophthalmic glass. The maximum iron $\left(\mathrm{Fe}_{2} \mathrm{O}_{3}\right)$ content ranges from $0.013 \%$ for optical glass to $0.3 \%$ for glass to insulating fibers [1].

It is known that quartz sand in the Ring of Fire region has low levels of silica contents because it is mixed with volcanic deposits. Java Island is a volcanic area that was formed in the Cenozoic period, producing a lot of quartz rock that settles, then affiliates with other rocks to form quartz sand mixed with other rocks [14]. Quartz sand in Sukabumi Regency is in the area around Mount Walat, which is in the south of Sukabumi City, West Java, Indonesia. Rock formations in the Mount Walat area were formed in the Eocene-Oligocene era, which was rich in quartz sand and fused to form conglomerate rocks. The rock formations were formed from seabed rocks, which raised to the surface along with Zircon, Tourmaline, Rutile and Apatite rocks [15]. Evidence that the rock formation of Mount Walat originated from the seabed was the presence of foraminifera deposits taken in the Batuasih area, Sukabumi Regency, West Java [16]. Therefore, quartz sand from the Sukabumi area has low silica content with many other impurities, so the use of quartz sand from Sukabumi as building materials is limited.

Even though Indonesia has very large reserves of silica, progressive studies on the deposition of this material are very few, resulting in limited applications of silica. In order to improve the added value of low-grade silica and obtain a high-level purity of silica from Sukabumi, which can be considered as important raw materials for special purposes mentioned above, the inherent impurities such as minerals and metals must be removed or reduced through efficient methods [17]. Increasing silica content in natural quartz sand is usually performed by removing impurities present in quartz sand in various ways based on silica levels presented in quartz sand. Therefore, studies are devoted to the implementation of alternative technological beneficiation method of silica, which is more effective and economical for industrial applications. That is, it is necessary to extend the understanding of the physical, chemical and physicochemical properties of raw materials for refining and removing impurities in the beneficiation process.

\section{Literature review and problem statement}

The paper [4] reported the improvement of low-grade silica using physical separation, such as screening, water scrubbing, froth flotation, shaking table and magnetic separator. The physical separation process is generally the initial process for quartz sand with low silica content ranging from $78 \%$ to $92 \%$ [4]. It is shown that the beneficiation of silica sand using a shaking table and magnetic separation increased the silica content to $98.9 \%$ and reduced the iron content to $0.05 \%$. However, these physical separation methods are less effective than chemical leaching. This is because the impurities in quartz sand are metallic, therefore strong acids are required to dissolve the metallic impurities. Therefore, quartz sand with a silica content of $92 \%$ to $95 \%$ needs further purification using the leaching process with strong acids such as sulfuric acid, hydrochloric acid and nitric acid [1]. The purification process to increase silica levels of $96 \%$ to $98 \%$ required an acid solution that has a solubility to dissolve impurities, which are still present in quartz sand. One of the materials used is oxalic acid, which is able to bind iron to form an iron oxalate solution, Fe (III) oxalate [18]. Based on the results of previous studies, the use of oxalic acid for the leaching process in high-level silica of $99.40 \%$ wt, with $0.029 \%$ wt of iron oxide content could reduce iron as much as $40 \%$ [19]. In addition to its use for high silica content, the extraction process using oxalic acid required high temperatures and a long time. The leaching process ranging between $90-100{ }^{\circ} \mathrm{C}$ for around 5 days was required in order to achieve $40 \%$ of iron extraction. The temperature change between $60-80{ }^{\circ} \mathrm{C}$ had no effect on iron dissolution. The leaching process with oxalic acid using a rotating column on a larger scale required 8 days to be able to produce silica with a small content of iron oxide impurity of $0.0163 \%$ [20].

The paper [5] reported the improvement of the quality of low-grade silica using the combination of indirect ultrasound irradiation with reverse flotation and magnetic separation. In this method, the granules in quartz sand were broken down to finer sizes with ultrasonic milling. The results of the study using water media with a combination of flotation and ultrasonic processes obtained silica contents of $98.43 \%$, with impurities of iron $0.034 \%$, alumina $0.90 \%$ and $\mathrm{TiO}_{2} 0.051 \%$ [5]. The dissolution process using oxalic acid without the ultrasonic process was able to remove $59.1 \%$ iron with an average grain size of $71.54 \mu \mathrm{m}$. The ultrasonic process with a power of 150 watts could remove iron up to $75.4 \%$ with a grain size up to $55.36 \mu \mathrm{m}$ [21]. Besides using oxalic acid and sulfuric acid in the ultrasonic process, phosphoric acid could be used for the innovation of the leaching process of quartz sand [22].

SA Boussaa et al studied the dissolution process of quartz sand using strong acids. The result showed that sulfuric acid gave the best results, which was able to take $97.96 \%$ iron and $94.23 \%$ aluminum impurities, while nitric acid was only able to take $90.5 \%$ iron oxide and $87.3 \%$ aluminum [17]. The research conducted by the Mineral Technology Research Center, Indonesia showed that the use of sulfuric acid for the leaching process of quartz sand was also better than the use of hydrochloric acid. The results of the leaching process of quartz sand from Sambiroto, Rembang, Central Java indicated that $4 \mathrm{~N} \mathrm{HCl}$ was only able to produce silica with iron oxide of $0.096 \%$ and alumina of $0.092 \%$, while $4 \mathrm{~N}$ sulfuric acid can produce silica with the content of iron oxide impurity of $0.0543 \%$ and alumina of $0.0587 \%$ [10]. The leaching process using sulfuric acid has also been developed not only at the laboratory scale but also at the pilot plant scale. Pilot scale experiments were conducted using rotary drums, which rotate continuously, with sulfuric acid and oxalic acid as leaching agents [6].

\section{The aim and objectives of the study}

The aim of this study is to remove iron and aluminum impurities from low-grade silica from quartz sand originated from Mount Walat, Sukabumi Regency, West Java, Indonesia with acid leaching using the sulfuric acid method.

To achieve the aim, the following objectives were set:

- to investigate the effect of reaction time and sulfuric acid concentration on the leaching process;

- to investigate the effectiveness of sulfuric acid for aluminum and iron oxide impurities removal; 
- to investigate the properties of the results by X-Ray Diffraction (XRD) analysis, X-Ray Fluorescence (XRF) and Scanning Electron Microscope-Energy Dispersive X-Ray (SEM-EDX).

\section{Materials and methods}

\section{1. Materials}

The sample of quartz sand was taken from Mount Walat Area, Sukabumi, West Java. The quartz sand was ground to get a powder form of quartz sand with a particle size of -200 mesh. The quartz sand powder was then washed with water two times and dried, then analyzed by XRD and XRF for characterization.

\section{2. Experimental procedure}

Before leaching, quartz sand was washed with clean water. After washing with water, it was dried to $110{ }^{\circ} \mathrm{C}$ for two hours, followed by the grinding process with a disk mill. After that, filtration was carried out to get silica sand with a grain size of -200 mesh, then the leaching process was performed with sulfuric acid. The process was done using fixed variables of volume, weight, temperature and speed of stirring process with $300 \mathrm{ml}$ sulfuric acid, $100 \mathrm{~g}$ quartz sand, temperature $90{ }^{\circ} \mathrm{C}$ and stirring speed $260 \mathrm{rpm}$, respectively. The variable changed in the first stage of the leaching experiment was the processing time, which is 1 hour, 2 hours, 3 hours, 4 hours and 5 hours with a sulfuric acid concentration of $8 \mathrm{~N}$. In the second stage, leaching was carried out with a sulfuric acid concentration of $2 \mathrm{~N}, 4 \mathrm{~N}, 6 \mathrm{~N}, 8 \mathrm{~N}, 10 \mathrm{~N}$ and $12 \mathrm{~N}$ and a leaching time of 5 hours. The results of all leaching processes were then washed with DI water, then the solid was dried at $110{ }^{\circ} \mathrm{C}$ for 2 hours. The dried solids were then analyzed by XRF, XRD and SEM analysis.

\section{Research results of aluminum and iron oxide removal from low-grade silica from quartz sand of Sukabumi}

5. 1. Investigating the effect of reaction time and sulfuric acid concentration on the leaching process

Observation of silica contents $\left(\mathrm{SiO}_{2}\right)$ in the quartz sand was conducted by XRF. In our previous study, we measured the contents of silica from the original quartz sand before treatment was done. The quartz sand originated from Mount Walat had low quality with a silica $\left(\mathrm{SiO}_{2}\right)$ content of $85.869 \%$. Therefore, quartz sand from this area is used as a building material and is very cheap.

The impurities contained in silica of the quartz sand from this area are dominated by aluminum oxide (alumina) and iron oxide. The washing process was performed two times to get a higher level of silica contents in the quartz sand. The first step of the washing process with water increased the contents of silica from $85.869 \%$ to $89.753 \%$ [23]. The second step of the washing process obtained the higher silica $\left(\mathrm{SiO}_{2}\right)$ content of $93.702 \%$, with the major impurities of the quartz sand being $\mathrm{Al}_{2} \mathrm{O}_{3}$ (4.691\%), $\mathrm{Fe}_{2} \mathrm{O}_{3}$ (0.641), $\mathrm{MgO}(0.273 \%)$ and $\mathrm{K}_{2} \mathrm{O}(0.414 \%)$.

After the washing process, the leaching experiment has been carried out using sulfuric acid with different leaching times of 1 hour, 2 hours, 3 hours, 4 hours and 5 hours. The results of the leaching process are indicated in Fig. 1 below.
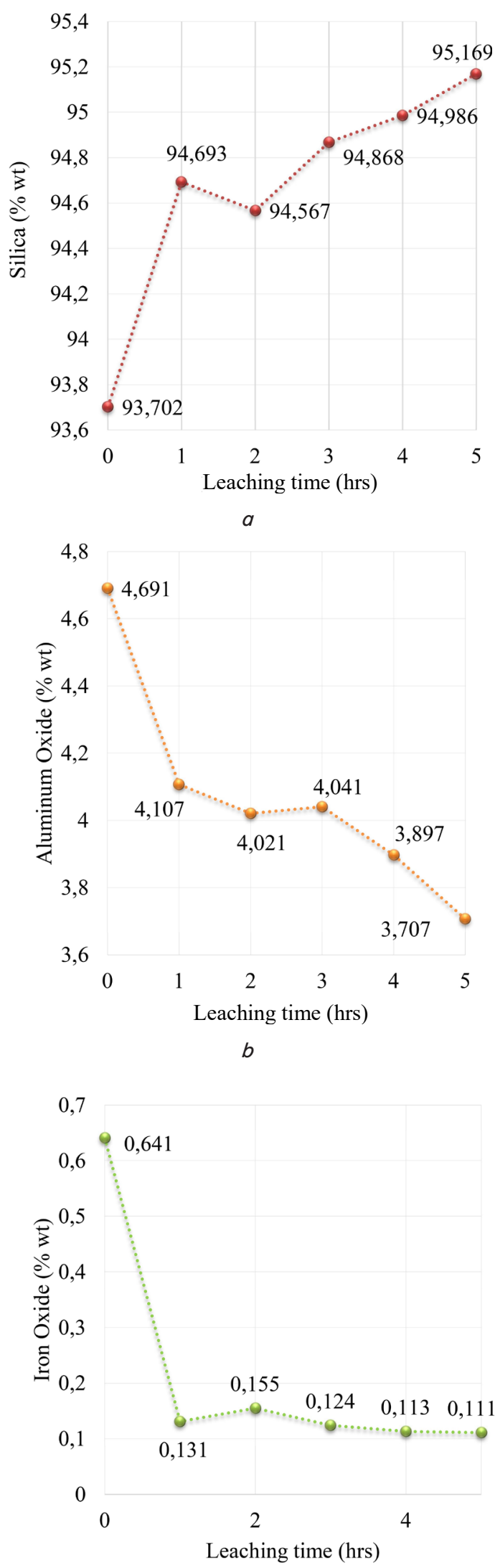

Fig. 1. Principal signature: $a-$ result of silica contents at different leaching times; $b$ - result of aluminum oxide contents at different leaching times; $c$ - result of iron oxide contents at different leaching times 
The results of the leaching process with $8 \mathrm{~N}$ sulfuric acid at different process times for silica, aluminum oxide and iron oxide are shown in Fig. 1. It is shown that the silica contents achieve the highest level of $95.169 \%$ with the leaching process for 5 hours, while aluminum oxide and iron oxide achieve the lowest content of $3.707 \%$ and $0.111 \%$, respectively for 5 hours of the leaching process. From this result, we investigated the effect of sulfuric acid concentration on the leaching process. The process was conducted at the leaching time of 5 hours. The result is shown in Fig. 2 below.

It can be seen in Fig. 2 that at the concentration of sulfuric acid of $10 \mathrm{~N}$, the silica content reached the highest increase from $95.506 \%$ to $96.438 \%$. On the other hand, the use of $10 \mathrm{~N}$ sulfuric acid reduces the aluminum and iron oxide content significantly from $3.421 \%$ to $2.712 \%$ and $0.101 \%$ to 0.094 , respectively.
5. 2. Investigating the effectiveness of sulfuric acid for aluminum and iron oxide impurities removal

In order to investigate the effectiveness of using sulfuric acid as a leaching solvent to eliminate aluminum and iron oxide, the percentage dissolution at different leaching times and different concentrations was observed. The result is shown in Fig. 3 below.

From the optimum point, the product then was measured by XRF analysis. The comparison of the starting material and the product after the leaching process is shown in Table 2.

The comparison of leaching efficiency of silica sand from different areas with the removal process of alumina and iron oxide impurities is shown in Table 3 below.

Note: Ratio - output/input ratio; Sukabumi - current experiment, leaching process using sulfuric acid; Jeddah - leaching process using magnetic separator [4]; Mojosari - leaching process using oxalic acid [1]; Iran - leaching process using oleic acid and assisted by ultrasonic, flotation and magnetic separator [5].

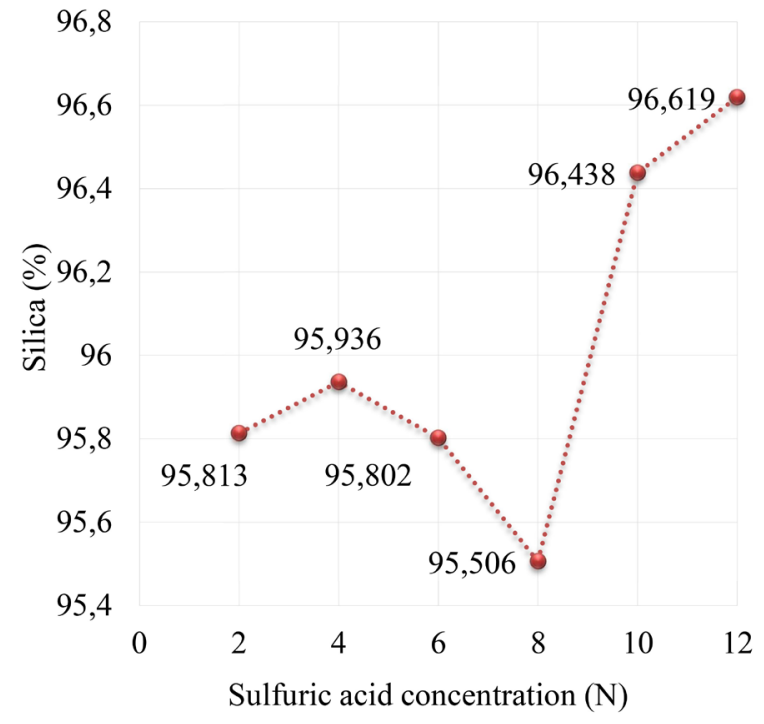

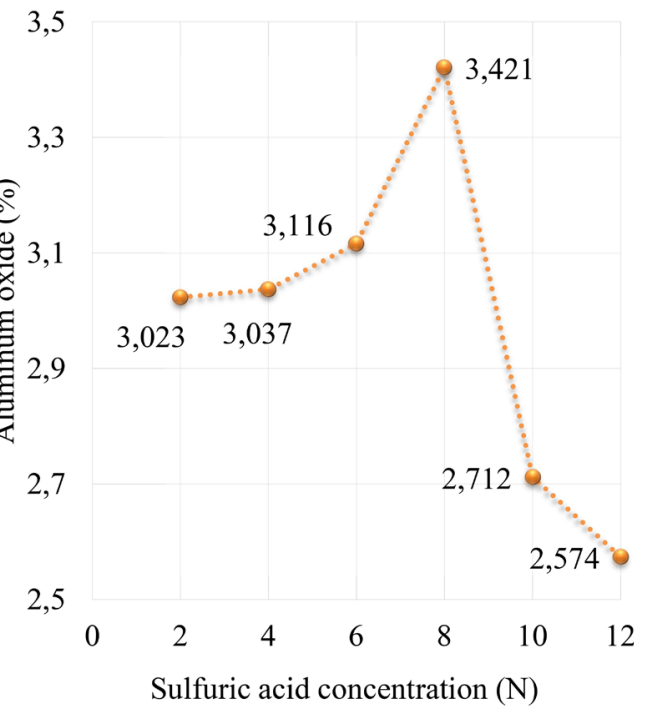

$b$

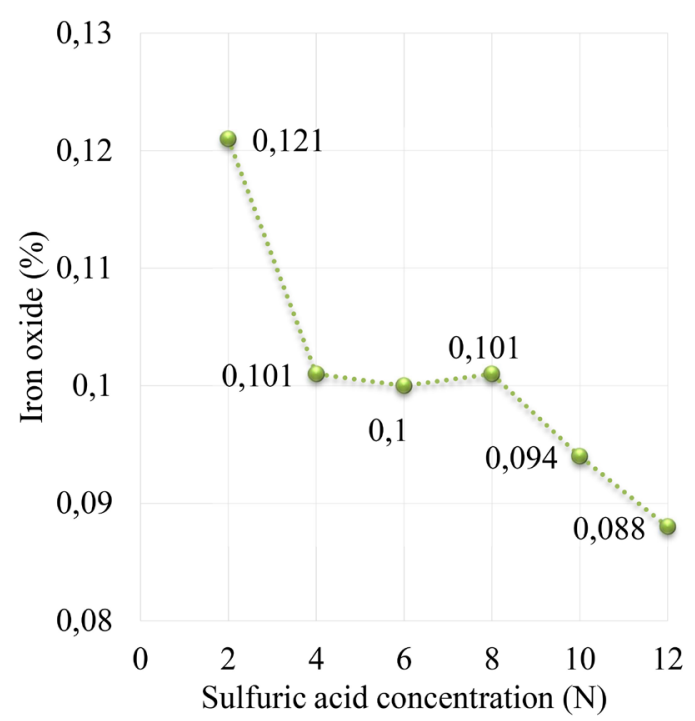

C

Fig. 2. Effect of sulfuric acid concentration on: $a$ - silica content; $b$ - aluminum oxide content; $c-$ iron oxide content 

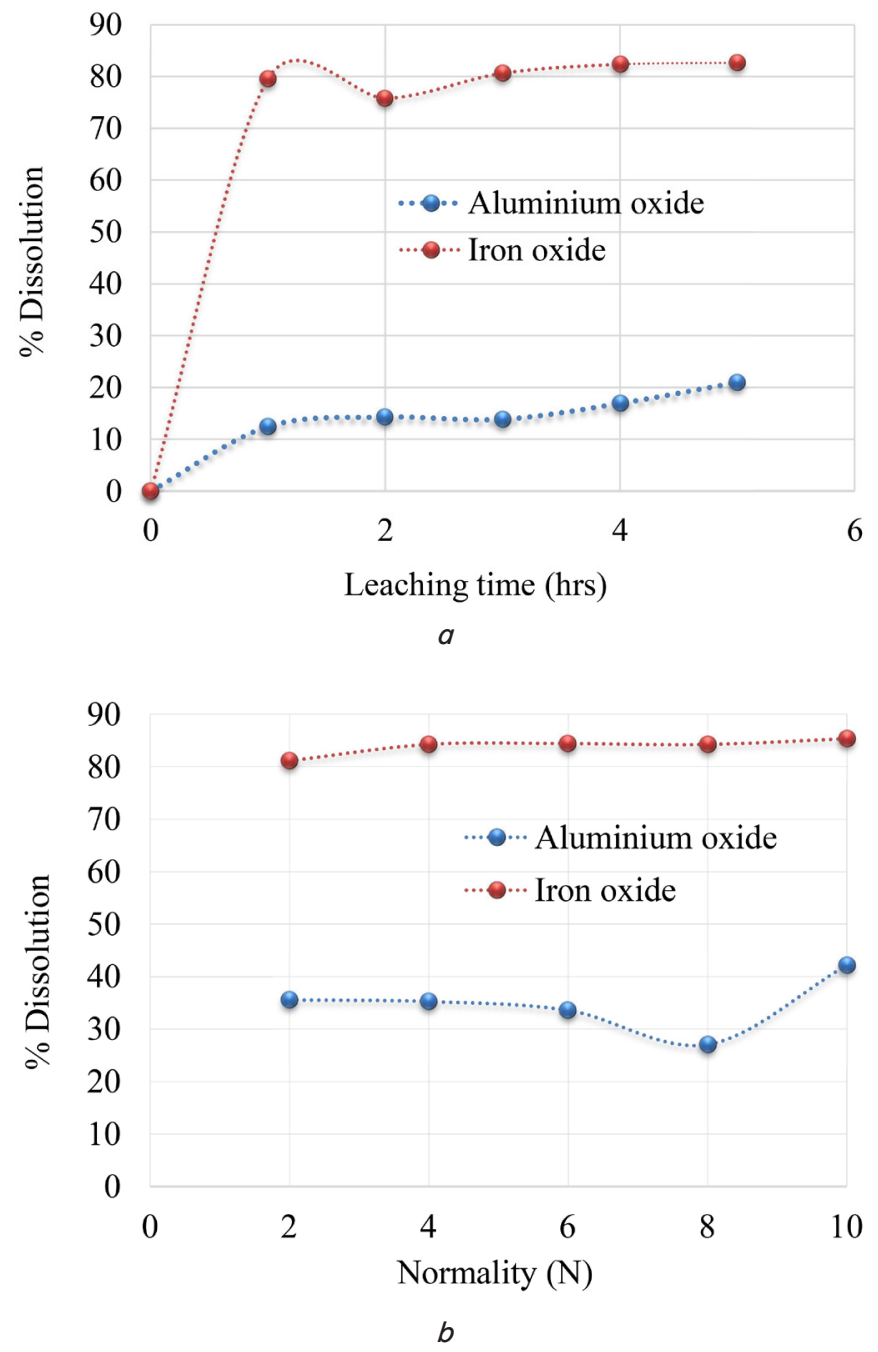

Fig. 3. Percentage of aluminum oxide and iron oxide dissolution: $a-$ at different leaching time; $b-$ at different normality of sulfuric acid

Table 2

XRF analysis of the starting material and the product after the leaching process

\begin{tabular}{|c|c|c|}
\hline Components & $\begin{array}{c}\text { Chemical composi- } \\
\text { tion (\%) of the } \\
\text { starting material }\end{array}$ & $\begin{array}{c}\text { Chemical composition (\%) } \\
\text { of the product after the } \\
\text { leaching process }\end{array}$ \\
\hline $\mathrm{SiO}_{2}$ & 93.702 & 96.438 \\
\hline $\mathrm{Al}_{2} \mathrm{O}_{3}$ & 4.691 & 2.712 \\
\hline $\mathrm{Fe}_{2} \mathrm{O}_{3}$ & 0.641 & 0.094 \\
\hline $\mathrm{MgO}$ & 0.273 & 0.124 \\
\hline $\mathrm{K} 2 \mathrm{O}$ & 0.414 & 0.257 \\
\hline $\mathrm{CaO}$ & 0.031 & Not detected \\
\hline $\mathrm{TiO}_{2}$ & 0.091 & 0.024 \\
\hline $\mathrm{SO}_{3}$ & 0.042 & 0.064 \\
\hline $\mathrm{P}_{2} \mathrm{O}_{5}$ & 0.011 & 0.004 \\
\hline $\mathrm{MnO}_{2}$ & 0.011 & 0.003 \\
\hline $\mathrm{Cr}_{2} \mathrm{O}_{3}$ & 0.067 & 0.077 \\
\hline
\end{tabular}

Table 3

Comparison of leaching efficiency of silica sand from different areas

\begin{tabular}{|c|c|c|c|c|}
\hline \multirow[b]{2}{*}{ No. } & \multirow[b]{2}{*}{ Country } & \multicolumn{3}{|c|}{ Chemical composition (\% wt) } \\
\hline & & $\begin{array}{c}\text { Silica } \\
\left(\mathrm{SiO}_{2}\right)\end{array}$ & $\begin{array}{c}\text { Alumina } \\
\left(\mathrm{Al}_{2} \mathrm{O}_{3}\right)\end{array}$ & $\begin{array}{l}\text { Iron oxide } \\
\left(\mathrm{Fe}_{2} \mathrm{O}_{3}\right)\end{array}$ \\
\hline \multirow{4}{*}{1} & $\begin{array}{c}\text { Sukabumi, } \\
\text { Indonesia }\end{array}$ & & & \\
\hline & Input & 93.702 & 4.691 & 0.641 \\
\hline & Output & 96.438 & 2.712 & 0.094 \\
\hline & Ratio & 1.029 & 0.578 & 0.147 \\
\hline \multirow{4}{*}{2} & $\begin{array}{c}\text { Jeddah, } \\
\text { Saudi Arabia }\end{array}$ & & & \\
\hline & Input & 92.70 & 3.60 & 0.40 \\
\hline & Output & 95.80 & 1.70 & 0.20 \\
\hline & Ratio & 1.033 & 0.472 & 0.500 \\
\hline \multirow{4}{*}{3} & $\begin{array}{l}\text { Mojosari, } \\
\text { Indonesia }\end{array}$ & & & \\
\hline & Input & 95.50 & 0.770 & 1.440 \\
\hline & Output & 97.79 & 0.058 & 0.253 \\
\hline & Ratio & 1.024 & 0.075 & 0.175 \\
\hline \multirow{4}{*}{4} & Iran & & & \\
\hline & Input & 96.87 & 1.54 & 0.114 \\
\hline & Output & 98.43 & 0.90 & 0.034 \\
\hline & Ratio & 1.016 & 0.584 & 0.298 \\
\hline
\end{tabular}

5. 3. Investigating the properties of the results by X-Ray Diffraction (XRD) analysis, X-Ray Fluorescence (XRF) and Scanning Electron Microscope-Energy Dispersive X-Ray (SEM-EDX)

In order to observe the grain morphology of the quartz sand, analysis was carried out by SEM. The analysis results for the starting material and the product obtained from the leaching process using sulfuric acid are shown in Fig. 4.

The element composition of the grain surface of the quartz sand before and after the leaching process was observed by EDX. The EDX observation was performed on the granules by taking a sample for each image as much as 3 points. The results can be seen in Table 4 .

Table 4

\section{Elements of the EDX results}

\begin{tabular}{|c|c|c|c|c|c|c|c|}
\hline \multirow{2}{*}{ No. } & \multirow{2}{*}{ Element } & \multicolumn{3}{|c|}{ Before leaching (\% wt) } & \multicolumn{3}{c|}{ After leaching (\% wt) } \\
\cline { 3 - 8 } & & Area 1 & Area 2 & Area 3 & Area 1 & Area 2 & Area 3 \\
\hline 1 & $\mathrm{O}$ & 40.2 & 51.8 & 40.9 & 59.0 & 50.4 & 52.6 \\
\hline 2 & $\mathrm{Si}$ & 14.2 & 26.2 & 9.3 & 40.8 & 49.0 & 44.6 \\
\hline 3 & $\mathrm{C}$ & 5.0 & 9.4 & 9.1 & 0.0 & 0.0 & 0.0 \\
\hline 4 & $\mathrm{Al}$ & 1.5 & 8.0 & 0.2 & 0.2 & 0.4 & 0.4 \\
\hline 5 & $\mathrm{Fe}$ & 0.2 & 2.7 & 30.2 & 0.0 & 0.0 & 2.3 \\
\hline 6 & $\mathrm{Mg}$ & 0.1 & 0.4 & 1.0 & 0.0 & 0.0 & 0.1 \\
\hline 7 & $\mathrm{Ca}$ & 0.0 & 0.0 & 0.0 & 0.0 & 0.2 & 0.0 \\
\hline 8 & $\mathrm{Zr}$ & 38.8 & 0.0 & 0.0 & 0.0 & 0.0 & 0.0 \\
\hline 9 & $\mathrm{~K}$ & 0.0 & 1.6 & 0.7 & 0.0 & 0.0 & 0.0 \\
\hline
\end{tabular}




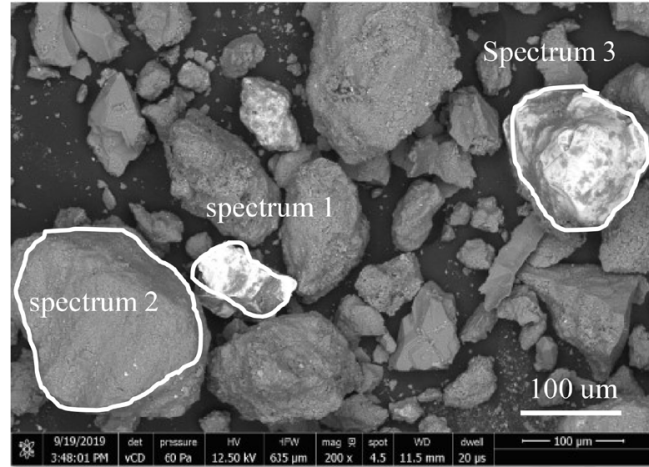

$a$

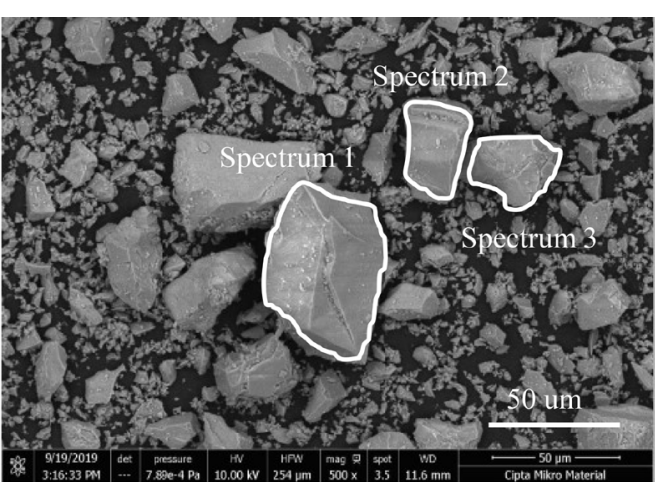

Fig. 4. Morphology observation, grain appearance of the starting material of quartz sand: $a$ - before leaching; $b$ - after leaching with sulfuric acid

It is seen from Table 4 that the elemental composition of $\mathrm{SiO}_{2}$ in the quartz sand after the leaching process raised significantly, which is indicated by increasing of the Si element from the average of $16.57 \%$ to $44.8 \%$. The content of aluminum oxide decreased from the average of $3.23 \%$ to $0.33 \%$, and the content of iron oxide decreased significantly from the average of $11.03 \%$ to $0.77 \%$.

The observation of the crystal structure of the starting material and the product was performed using XRD analysis. The results are shown in Fig. 5 .

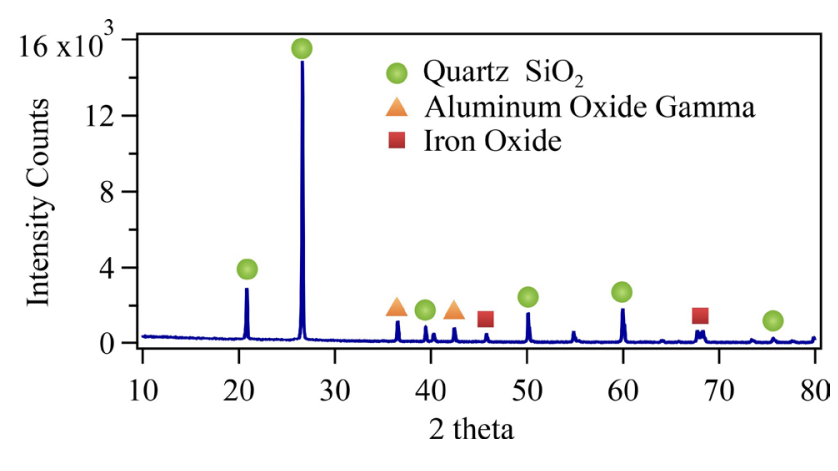

$a$

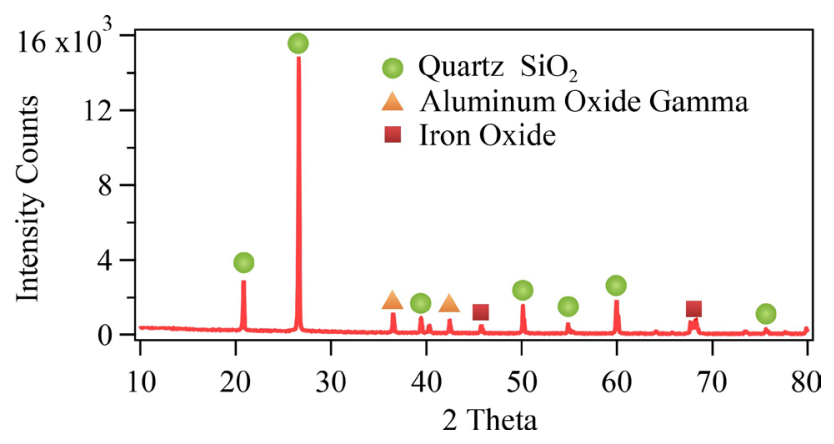

$b$

Fig. 5. XRD analysis results for: $a-$ starting material; $b$ - product obtained from the leaching process using $10 \mathrm{~N}$ sulfuric acid for 5 hours

Comparison of quartz sand from raw material after washing with water and after leaching with sulfuric acid is shown in the following Fig. 6.

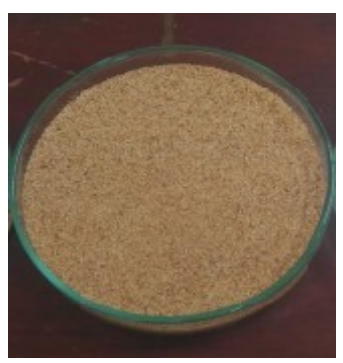

$a$

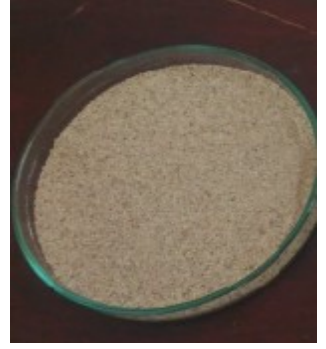

$b$

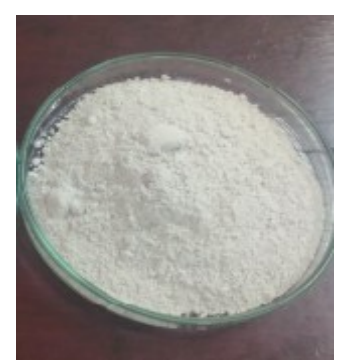

C

Fig. 6. Principal signature; $a-$ quartz sand before washing; $b$ - quartz sand after the second step of washing but before leaching; $c$ - quartz sand after leaching with sulfuric acid

It is shown from the grain observations of quartz sand in Fig. 6 that quartz sand produced from the leaching process using sulfuric acid had different shapes and colors of grains. After the leaching process, the granules become smooth, light and white, due to the significant reduction of aluminum and iron impurities.

\section{Discussion of the research results of aluminum and iron oxide removal from low-grade silica from quartz sand of Sukabumi}

The results of the leaching process with different reaction times are shown in Fig. 1. It appeared that there was no significant change in the increase of silica content before 3 hours. At the leaching time of 1 hour, there was an increase of the silica level from $93.702 \%$ to $94.693 \%$. It was possible that sulfuric acid started to dissolves impurities in the form 
of a soluble single compound on the surface of the granules. At intervals of 1 hour to 3 hours, there was no increase of silica levels, which showed the initiation process between sulfuric acid with impurities. The optimum point was at 5 hours with silica contents of $95.169 \%$. The results of observation on aluminum and iron oxide impurities showed a trend of decreasing levels similar to an increasing trend in silica levels. The leaching time of 1 hour showed a significant decrease. The decreasing process was not stable at 1-3 hours, and there is a slight increase in concentration at 2 hours. At intervals of 3 to 5 hours, the impurity level decreased with increasing time, and the impurities of aluminum and iron oxide at 5 hours were $2.574 \%$ and $0.088 \%$, respectively.

Fig. 2 showed the effect of the leaching process at different concentrations of sulfuric acid on the silica, aluminum and iron oxide contents. It indicated that dilute sulfuric acid solution with the normality of $2 \mathrm{~N}$ up to $8 \mathrm{~N}$ showed a small increase of the silica level (Fig. 2,a). The optimum level of increasing silica occurred at $10 \mathrm{~N}$, in which silica $\left(\mathrm{SiO}_{2}\right)$ content increased from 95.506 to $96.438 \%$, while increasing the concentration of sulfuric acid to $12 \mathrm{~N}$ did not increase the silica content significantly.

Analysis of the results of decreasing the impurities of alumina and iron oxide indicated that the content of impurities decreased with the increasing normality of sulfuric acid, with decreasing significant point in a certain value. The alumina removal showed a significant reduction from $3.421 \%$ to $2.712 \%$ with increasing sulfuric acid concentration from $8 \mathrm{~N}$ to $10 \mathrm{~N}$ (Fig. 2, $b$ ), however, when the sulfuric acid concentration increased to $12 \mathrm{~N}$, there was no significant effect on alumina reduction. The significant reduction of iron oxide impurity occurred from $0.121 \%$ to $0.101 \%$ at the concentration of sulfuric acid from $2 \mathrm{~N}$ to $4 \mathrm{~N}$ (Fig. 2,c). From this analysis, it is clear that the concentration of sulfuric acid gives a significant effect on the reduction of the impurities. The increasing sulfuric concentration gives rise to the decrement of the impurities to a certain value, hence increases the level of silica content.

The effectiveness of sulfuric acid for alumina and iron oxide impurities removal is shown in Fig. 3. It shows that the leaching process using $8 \mathrm{~N}$ sulfuric acid at the leaching time of 5 hours gave the percentage of alumina and iron oxide dissolution of $21 \%$ and $83 \%$, respectively (Fig. 3, $a$ ). After the leaching process with different normality of sulfuric acid was increased to $10 \mathrm{~N}$ for 5 hours, the alumina and iron oxide dissolution escalated to $42 \%$ and $85 \%$, respectively (Fig. 3, $b$ ). From this result, it can be concluded that the optimum point of the dissolution process of aluminum and iron impurities is at the leaching time of 5 hours with the normality of sulfuric acid of $10 \mathrm{~N}$. At this optimum point, sulfuric acid is very effective to remove the impurities of aluminum up to $42 \%$ and iron with the maximum value up to $85 \%$.

The enhancement of the silica contents from $93.702 \%$ to $96.438 \%$, which is shown in Table 2, indicates that the reduction of many impurities by the leaching process with sulfuric acid is successful. Significantly reduced impurities after the leaching process with sulfuric acid at a concentration of $10 \mathrm{~N}$ and leaching time of 5 hours are aluminum oxide, iron oxide, manganese oxide, potassium oxide, manganese oxide, titanium oxide and phosphor oxide. However, there are several impurities that slightly increase such as sulfur, chromium oxide and small traces of elements.

The mechanism of the leaching process using sulfuric acid for alumina and iron oxide impurities can be explained as follows: sulfuric acid in solution produced $\mathrm{H}^{+}$that will interact with the impurities of alumina and iron oxide. The possible reaction is:

$$
\begin{aligned}
& 6 \mathrm{H}^{+}+\mathrm{Al}_{2} \mathrm{O}_{3} \rightarrow 2 \mathrm{Al}^{3+}+3 \mathrm{H}_{2} \mathrm{O}, \\
& 6 \mathrm{H}^{+}+\mathrm{Fe}_{2} \mathrm{O}_{3} \rightarrow 2 \mathrm{Fe}^{3+}+3 \mathrm{H}_{2} \mathrm{O} .
\end{aligned}
$$

Based on the reaction above, the reduction of the alumina and iron oxide impurities will depend on the concentration of the impurities and also the concentration of sulfuric acid in the leaching process. Therefore, the reduction of the alumina and iron oxide impurities of low-level silica of quartz sand is not easier compared with those from the high-purity silica sand.

In order to investigate the leaching efficiency of our work, a comparison with the other's experiment is conducted (Table 3). The smaller the ratio of alumina and iron oxide removal, the better the efficiency of the leaching process. It is seen that the ratio of our work for alumina removal is 0.578 and smaller than the ratio of the alumina reduction in silica sand from Iran, which has the ratio of 0.584 . Thus, the leaching efficiency for removing alumina impurities of our work is higher than that of [5]. The ratio of the iron oxide removal of the current experiment in our work is 0.147 , which is smaller than in the other's work. This indicates that the high efficiency of iron oxide removal from low-grade silica is obtained by our technique. For the silica content, the higher ratio of $\mathrm{SiO}_{2}$ indicates the higher leaching efficiency (Table 3). Our work shows the ratio of $\mathrm{SiO}_{2}$ with the value of 1.029 , which is higher than that of $[1,5]$. This also means that our process produces a high efficiency of increasing silica content in quartz sand.

Fig. 4 showed the results of the grain appearance of quartz sand by SEM measurement. It is seen that the quartz sand from Sukabumi as the initial material for the experiment has other components besides quartz $\left(\mathrm{SiO}_{2}\right)$ crystal. Dark and bright color in grain appearance was present. After leaching with sulfuric acid, the granules were relatively similar. The leaching process produced more uniform grains, which also indicated a reduction in impurities.

In order to observe the elements of the quartz sand, EDX analysis was performed on the grain surface. The results of EDX analysis show that there are greater diversities of elements for the starting material compared to the products after the leaching process with sulfuric acid. Zircon mineral $\left(\mathrm{ZrSiO}_{4}\right)$ of $38.8 \%$ is found for the starting material (Table 4). The carbon element in the quartz sand from Sukabumi shows that there are organic compounds, while the product after the leaching process does not contain carbon. This means that sulfuric acid is also effective to remove zircon and other organic compounds. This is evidenced by the absence of zircon and organic compounds in the product. It is seen from EDX analysis that there are elements that bind to quartz sand forming complex bonds. Therefore, it is necessary to carry out the purification process by breaking down the granules into the smallest possible for the grain size, one of the methods is by using an ultrasonic milling or ultrasonic cleaning process [24].

The XRD analysis is shown in Fig. 5. The quartz after the leaching process with sulfuric acid with a concentration of $10 \mathrm{~N}$ and 5 hours did not show a phase change when compared with the initial material before the leaching process. Based on the Match standard with ICSD number: 96-901-2601, the visible phase of the silicon oxide compound was quartz $\left(\mathrm{SiO}_{2}\right)$, not cristobalite. The cristobalite phase 
required a temperature of $1400{ }^{\circ} \mathrm{C}$ and was cooled suddenly [25]. The XRD analysis results, in addition to the $\mathrm{SiO}_{2}$ quartz phase, also found aluminum oxide gamma compounds and iron oxide.

From the grain observation of quartz sand in Fig. 6, it is seen that there is a noticeable change in the appearance of granules in color. The initial material has a reddish color (Fig. 6, $a$ ), the result of washing before the leaching process is whiter (Fig. 6,b) compared with the quartz before washing, and the color after leaching with sulfuric acid turns to pure white (Fig. 6, $c$ ).

The results of this study indicate that the removal of the impurities of low-grade silica from Sukabumi is performed successfully by the leaching process using sulfuric acid. The content of iron oxide and alumina decreased significantly. Iron oxide and alumina contents of the product after leaching are $0.094 \%$ and $2.712 \%$, respectively. The content of silica raised from $93.702 \%$ to $96.438 \%$. This can be a very significant opportunity to increase the value added of quartz sand from Sukabumi, which can enhance the quality of low-grade silica sand to provide better raw materials for glass industries [1].

The shortcoming of this research, the leaching process using sulfuric acid assisted by the ultrasonic method is not investigated. The ultrasonic process can break down the granules into the smallest size to get finer silica sand and impurities which form complex bonds can be more easily dismissed. Besides that, the impurities elimination rate can be enhanced by using the ultrasonic technique combined with sulfuric acid so that aluminum and iron oxide can be eliminated more efficiently.

Several things can be improved in this research. Increase the leaching time and sulfuric acid concentration. Optimize the process parameters such as temperature parameters in the leaching process. Use the ultrasonic process in the leaching process using sulfuric acid with several parameters such as amplitude and frequency.

\section{Conclusions}

1. Iron and aluminum impurities removal from low-grade silica from quartz sand of the Mount Walat area, Sukabumi, Indonesia was done successfully using sulfuric acid leaching. The results of the leaching process indicated the optimum point of the leaching process with the normality of $10 \mathrm{~N}$ sulfuric acid and leaching time of 5 hours.

2. Sulfuric acid is very effective to remove aluminum and iron impurities up to $42 \%$ and $85 \%$, respectively, and the silica content increases from $93.702 \%$ to $96.438 \%$.

3. The results of SEM-EDX analysis showed that silica sand from Mount Walat, Sukabumi had a variety of mineral forms with quartz as primary minerals, which had major impurities of aluminum and iron oxide. After undergoing the leaching process with sulfuric acid, the SEM-EDX analysis result showed relatively uniform grain shapes. The XRD analysis for the leaching product showed no phase change during the leaching process, where the main phase was still in the form of quartz $\left(\mathrm{SiO}_{2}\right)$ phase. The results of this study can improve the quality of low-grade silica contents from quartz sand resources and provide better raw materials for glass industries.

\section{Acknowledgments}

The experiments were carried out using laboratory facilities in the Research Center for Metallurgy and Materials, Indonesian Institute of Sciences (LIPI). The authors gratefully acknowledge the financial support provided by the Grant of PPTI from the Minister of Research and Technology with No. 48/E1/ KPT/2020. The authors also acknowledge the analytical instrumentation facility from ELSA (E-Layanan Sains) - Indonesian Institute of Sciences (LIPI) for the characterization of the materials.

\section{References}

1. Suratman (2015). Removal of Metallic Impurities From Quartz Sand Using Oxalic Acid. Indonesian Mining Journal, 18 (3), 133-141. Available at: https://jurnal.tekmira.esdm.go.id/index.php/imj/article/view/262/167

2. Chammas, E., Panias, D., Taxiarchou, M., Anastasakis, G. N., Paspaliaris, I. (2001). Removal of iron and other major impurities from silica sand for the production of high added value materials. Proceedings of the 9th Balkan Mineral Processing Congress, 289-295. Available at: https://www.researchgate.net/publication/234107519_Removal_of_iron_and_other_major_impurities_from_silica_ sand_for_the_production_of_high_added_value_materials

3. Banza, A. N., Quindt, J., Gock, E. (2006). Improvement of the quartz sand processing at Hohenbocka. International Journal of Mineral Processing, 79 (1), 76-82. doi: https://doi.org/10.1016/j.minpro.2005.11.010

4. Al-Maghrabi, M.-N. (2004). Improvement of Low-Grade Silica Sand Deposits In Jeddah Area. Journal of King Abdulaziz University-Engineering Sciences, 15 (2), 113-128. doi: https://doi.org/10.4197/eng.15-2.8

5. Haghi, H., Noaparast, M., Shafaei Tonkaboni, S., Mirmohammadi, M. (2016). A New Experimental Approach to Improve the Quality of Low Grade Silica; The Combination of Indirect Ultrasound Irradiation with Reverse Flotation and Magnetic Separation. Minerals, 6 (4), 121. doi: https://doi.org/10.3390/min6040121

6. Veglió, F., Passariello, B., Barbaro, M., Plescia, P., Marabini, A. M. (1998). Drum leaching tests in iron removal from quartz using oxalic and sulphuric acids. International Journal of Mineral Processing, 54 (3-4), 183-200. doi: https://doi.org/10.1016/ s0301-7516(98)00014-3

7. Wahyuningsih, S., Suharty, N. S., Pramono, E., Ramelan, A. H., Sasongko, B., Dewi, A. O. T. et. al. (2018). Iron and boron removal from sodium silicate using complexation methods. AIP Conference Proceedings, 1964. doi: https://doi.org/10.1063/1.5038303

8. Bessho, M., Fukunaka, Y., Kusuda, H., Nishiyama, T. (2009). High-Grade Silica Refined from Diatomaceous Earth for Solar-Grade Silicon Production. Energy \& Fuels, 23 (8), 4160-4165. doi: https://doi.org/10.1021/ef900359m

9. Buttress, A. J., Rodriguez, J. M., Ure, A., Ferrari, R. S., Dodds, C., Kingman, S. W. (2019). Production of high purity silica by microfluidic-inclusion fracture using microwave pre-treatment. Minerals Engineering, 131, 407-419. doi: https://doi.org/10.1016/ j.mineng.2018.11.025 
10. Suratman, S., Handayani, S. (2014). Beneficiation of Sambiroto Silica Sand By Chemical And Biological Leachings. Indonesian Mining Journal, 17 (3), 134-143. Available at: https://jurnal.tekmira.esdm.go.id/index.php/imj/article/view/318/201

11. Štyriaková, I., Mockovčiaková, A., Štyriak, I., Kraus, I., Uhlík, P., Madejová, J., Orolínová, Z. (2012). Bioleaching of clays and iron oxide coatings from quartz sands. Applied Clay Science, 61, 1-7. doi: https://doi.org/10.1016/j.clay.2012.02.020

12. Wahyuningsih, S., Ramelan, A. H., Suharty, N. S., Handayani, M., Firdiyono, F., Sulistiyono, E. et. al. (2018). Phosphorus Elimination at Sodium Silicate from Quartz Sand Roasted with Complexation using Chitosan-EDTA. IOP Conference Series: Materials Science and Engineering, 333, 012050. doi: https://doi.org/10.1088/1757-899x/333/1/012050

13. Febriana, E., Manurung, U. A. B., Prasetyo, A. B., Handayani, M., Muslih, E. Y., Nugroho, F. et. al. (2020). Dissolution of quartz sand in sodium hydroxide solution for producing amorphous precipitated silica. IOP Conference Series: Materials Science and Engineering, 858, 012047. doi: https://doi.org/10.1088/1757-899x/858/1/012047

14. Smyth, H. R., Hall, R., Nichols, G. J. (2008). Significant Volcanic Contribution to Some Quartz-Rich Sandstones, East Java, Indonesia. Journal of Sedimentary Research, 78 (5), 335-356. doi: https://doi.org/10.2110/jsr.2008.039

15. Clements, B., Hall, R. (2006). Provenance of Paleogene sediments in West Java, Indonesia. Proceedings of the International Geosciences Conference and Exhibition. Jakarta, 1-5. Available at: http://searg.rhul.ac.uk/pubs/clements_hall_2006\%20West\%20 Java\%20provenance_IPA.pdf

16. Hendrizan, M., Praptisih, P., Putra, P. S. (2012). Depositional Environment of the Batuasih Formation on the Basis of Foraminifera Content: A Case Study in Sukabumi Region, West Java Province, Indonesia. Indonesian Journal on Geoscience, 7 (2). doi: https:// doi.org/10.17014/ijog.v7i2.139

17. Anas Boussaa, S., Kheloufi, A., Boutarek Zaourar, N., Bouachma, S. (2017). Iron and Aluminium Removal from Algerian Silica Sand by Acid Leaching. Acta Physica Polonica A, 132 (3-II), 1082-1086. doi: https://doi.org/10.12693/aphyspola.132.1082

18. Vegliò, F., Passariello, B., Abbruzzese, C. (1999). Iron Removal Process for High-Purity Silica Sands Production by Oxalic Acid Leaching. Industrial \& Engineering Chemistry Research, 38 (11), 4443-4448. doi: https://doi.org/10.1021/ie990156b

19. Taxiarchou, M., Panias, D., Douni, I., Paspaliaris, I., Kontopoulos, A. (1997). Removal of iron from silica sand by leaching with oxalic acid. Hydrometallurgy, 46 (1-2), 215-227. doi: https://doi.org/10.1016/s0304-386x(97)00015-7

20. Ubaldini, S., Piga, L., Fornari, P., Massidda, R. (1996). Removal of iron from quartz sands: A study by column leaching using a complete factorial design. Hydrometallurgy, 40 (3), 369-379. doi: https://doi.org/10.1016/0304-386x(95)00012-6

21. Du, F., Li, J., Li, X., Zhang, Z. (2011). Improvement of iron removal from silica sand using ultrasound-assisted oxalic acid. Ultrasonics Sonochemistry, 18 (1), 389-393. doi: https://doi.org/10.1016/j.ultsonch.2010.07.006

22. Zhang, Z., Li, J., Li, X., Huang, H., Zhou, L., Xiong, T. (2012). High efficiency iron removal from quartz sand using phosphoric acid. International Journal of Mineral Processing, 114-117, 30-34. doi: https://doi.org/10.1016/j.minpro.2012.09.001

23. Sulistiyono, E., Handayani, M., Prasetyo, A. B., Irawan, Y., Febriana, E., Sembiring, S. N., Yustanti, E. (2020). Identification of Quartz Sand From the Hills of Gunung Walat at Sukabumi Regency for Raw Materials of Nano Silica Precipitate. IOP Conference Series: Materials Science and Engineering, 858, 012048. doi: https://doi.org/10.1088/1757-899x/858/1/012048

24. Zhao, H. L., Wang, D. X., Cai, Y. X., Zhang, F. C. (2007). Removal of iron from silica sand by surface cleaning using power ultrasound. Minerals Engineering, 20 (8), 816-818. doi: https://doi.org/10.1016/j.mineng.2006.10.005

25. Kazemi, A., Faghihi-Sani, M. A., Alizadeh, H. R. (2013). Investigation on cristobalite crystallization in silica-based ceramic cores for investment casting. Journal of the European Ceramic Society, 33 (15-16), 3397-3402. doi: https://doi.org/10.1016/ j.jeurceramsoc.2013.06.025 